\title{
AMD の可動限界を考慮した可変フィードバックゲイン制御による制震 VARIABLE GAIN-BASED STRUCTURAL CONTROL ACCOUNTING FOR THE LIMIT OF AMD MOVEMENT
}

\author{
西谷 章*, 仁田佳宏** \\ Akira NISHITANI and Yoshihiro NITTA
}

\begin{abstract}
Active structural-control is a new technology of earthquake resistance strategy for civil structures. This technology, however, is currently under way of development, having some issues to be solved. One of the most significant issues is how to control buildings regardless of earthquake severeness. This paper presents variable gain-based structural control accounting for AMD stroke limitation. The control algorithm is based on the philosophy of Maximal admissible set of initial state, which was originally proposed for a system with no input excitation. Simulated and experimental results demonstrates how effectively and satisfactorily the presented methodology works.
\end{abstract}

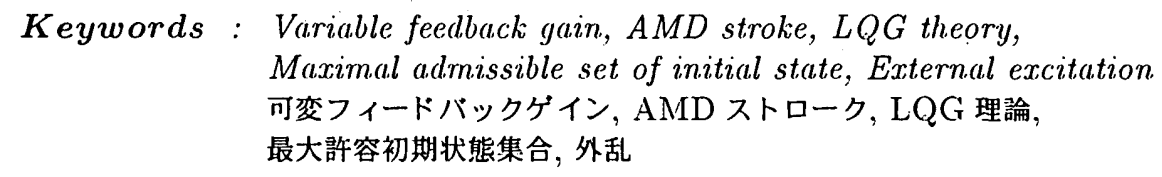

\section{1 はじめに}

近年の急速な科学技術の発展は, 多くの工学分野において, 従来 のあり方を超えた発想を現実のものとし始めている。建築分野にお けるアクティフ制震はこの代表例のひとつであり，次世代の耐震構 造としての期待も大きく，これまでにもアクティブ制震を中心とし た国際的な共同活動も展開されている2!。現在のアクティブ制震構 造は, AMD や HMD のような付加的な質量を駆動させることに より発生する慣性力を制御力として利用する方式を基本としてい るものが多い3)。一般に，あらゆる制御装置はそれぞれ性能限界を もつが，この AMD あるいは HMD 方式においては，可動限界や この付加的な質量を駆動させるために加える力などに対して限界 があり, 残念ながら現在のところ, あらゆる地震動に対応可能なも のとはなっていない。本論文は，AMDにかかわる性能限界を考慮 したフィードバックゲイン制御の開発を目的に, 地震動の大きさに よらず適用可能な制御システムとして，AMD のストローク限界 (AMDや HMD の動き (変位) を「ストローク」と呼ぶ) を考急 した可変フィードバックゲイン制御システムの設計法を示し, その 有効性を示す。

AMD 方式における制御装置の性能制約としては，AMDに加 えるカとストロークがある。AMD に加えるカにかかわる制約を
考虑する場合には，Bang-Bang 制御に代表される飽和制御によ り，大地震時までの効果的な制御が可能となる ${ }^{4,5)}$ 。しかし，飽和 制御は, 制御力の拘束への対処を目的としていおり, AMD のスト ローク限界を対処するには不向きである。

このストローク限界を考虏するために, AMD の状態によりゲイ ンを切り替える可変フィードバックゲイン制御が提案され $\left.{ }^{6} 9\right)$, 実 棈造物への適用を通してその効果が実証されているものもある8,9)。 しかしながら，これらの可変フィードバックゲイン制御の多くは，ゲ イン切り替えの判断基準となる, AMD の状態 (ストロークと速 度)に関する闌値レベルの設定が試行錯誤的であり，合理的な設定 となっている保証はない。また, 複数のゲインを 1 夜数の連続関数 に近似し，合理的にゲイン切り替えを行う制御 ${ }^{10)} も$ 提案されてい るが,この場合には, AMD のストロークを予测しなければならな い。さらに, 㗪存の手法の多くは, AMD の速度とストロークのみ をゲイン切り替えの判断基準に用いており，建築構造物の状熊を加 味してゲインを切り替えている可変フィードバックゲイン制御はほ とんど見られない。本論文では, AMD と建築物の状態を考慮した 可変フィードバックゲイン制御を目的として，最大吘容初期状態集 合11を用いて，合理的なゲインの切り品えを提案する。この最大許 容初期状態集合を用いた制御アルゴリズムは, もともと外乱のない

本諭文は, 35th IEEE Conference on Decision and Control で発裴した内容(文献1)をもとに，あらたな計算，あらたな実験により大幅な修正を加えたものである。
*早稻田大学理工学部建築学科 教授・Ph. D.・エ博 Prof., Dept. of Architecture, Waseda Univ., Ph. D., Dr. Eng.

** 早稲田大学大学院 大学院生・修士(工学) Graduate Student, Dept. of Architecture, Waseda Univ., M. Eng. 


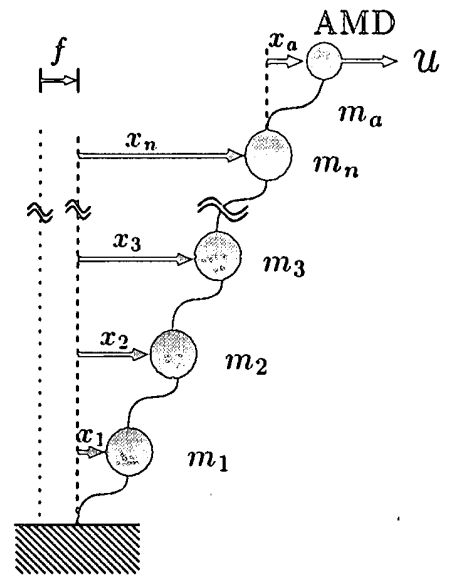

Figure 1 Building Model with AMD

システム用に開発されたものであるが，外乱を受ける䄜造物に応用 する。

2 可変フィードバックゲイン制御

2.1 状態フィードバックゲインの設計

AMD 方式の制震橖造においては, 制御コンピュータからの出 カである制御信号にしたがって，アクチユエータが AMDにカを 加え, AMD を駆動する。制御工学的には, AMD の動きによって 生ずる㙁性力を「制御入力」とする定式化も可能であるが，以下の 定式化にあたっては, 制御コンピュータか゚アクチュエータを介して AMD に加える力を「制御入力」としてスカラー量 $u$ で表し，以 下「制御力」と呼ぶことにする。

Fig.1 に示すような AMD による $n$ 首㔍造物の振動制御を考 える。因に示す座標系を用いて, AMD の動きを含む構造物全体の 状態 $X$ を以下のように表す：

$$
\begin{aligned}
& X(k)=\left[\begin{array}{llll}
\dot{x}_{1}(k) & \cdots & \dot{x}_{n}(k) & \dot{x}_{a}(k)
\end{array}\right. \\
& \left.x_{1}(k) \cdots x_{n}(k) x_{a}(k)\right]^{T}
\end{aligned}
$$

ただし, $x_{i}(k)$ は, $\Delta t$ を離散時間幅として, 時刻 $k \Delta t$ における $x_{i}$ の值を意味してる。また右局の上添字 $T$ は䎐置を表している。

この制震建物の離散時間状態方程式を以下のように表す。

$$
X(k+1)=A X(k)+B u(k)+E f(k)
$$

ただし， $u(k)$ : 時刻 $k \Delta t$ における制御力 (スカラー) $; f(k):$ 時 刻 $k \Delta t$ における外乱 (スカラー)；A: AMD と $n$ 屏粠造物 の特性を表す $2(n+1)$ 行 $\times 2(n+1)$ 列の雄散時間システム行 列 ; $B$ : 制御力の作用位盟を示す $2(n+1)$ 行のベクトル $; E:$ 外 乱の作用位䍡を示す $2(n+1)$ 行のペクトル，となる。

制御力 $u(k)$ 決定のためのフィードバックケ゚イン (以降，表記を 简略化するため, FB ゲイン, と表すことにする) は, $M$ 個の FB ゲイン $G_{m}(m=1 \sim M)$ の中から各時刻ことに 1 つ選ばれる ものとする。制御力 $u(k)$ は次のように決定される。

$$
u(k)=G_{m} X(k)
$$

$G_{m}$ は, LQG 理論を用いて以下の評価関数，J，を最小にするよう に決めるものとする。

$$
J=\frac{1}{2} \sum_{k=0}^{\infty}\left[X^{T}(k) Q_{m} X(k)+r u(k)^{2}\right]
$$

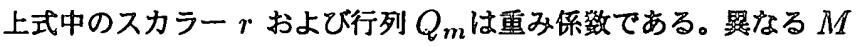
個の $Q_{m}$ を用いて, 次の離散リカッチ方程式 :

$$
P_{m}=Q_{m}+A^{T} P_{m} A-A^{T} P_{m} B\left[r+B^{T} P_{m} B\right]^{-1} B^{T} P_{m} A
$$

を $P_{m}$ について解き, $P_{m}$ から $G_{m}$ を以下のように求元。

$$
G_{m}=-\left[r+B^{T} P_{m} B\right]^{-1} B^{T} P_{m} A
$$

本論文では, $Q_{m}$ を以下のように設定する。

$$
Q_{m}=\operatorname{diag}\left[q_{1}^{\prime}, \cdots, q_{n}^{\prime}, q_{a}^{\prime}, q_{1}, \cdots, q_{n}, q_{a}\right]
$$

ただし， $\operatorname{diag}[] ：$ [ ] の要素を対角要素とする対角行列 $q_{a}^{a}: \mathrm{AMD}$ の速度にかかる画み $q_{a}: \mathrm{AMD}$ のストロークにかかる雷み $q_{i}^{\prime}:$ 權造物の $i$ 層の速度にかかる重み このとき, $q_{i}:$ 構造物の $i$ 莌の変位にかかる重み。

$$
q_{1}^{\prime}: q_{2}^{\prime}: \cdots: q_{n}^{\prime}: q_{a}^{\prime}: q_{1}: q_{2}: \cdots: q_{n}
$$

の比を常に一定とすれぱ, $q_{a} / q_{n}^{\prime}$ が大きくなるように設定するに したがって, 制御の主目的が構造物の応答低隇から AMD のスト ロークの低減へと移る。すなわち, $q_{a} / q_{n}$ が小さいほど, 制御勃 果が高く, AMD のストロークを䅡極的に使う FB ゲインとな り, $q_{a} / q_{n} \dot{n}$ が大きいほど, AMD のストロークは小さいが, 制御 勃界は低い FB ケ゚インとなる。本論文では, AMD のストローク にかかる重み $q_{a}$ を変化させることで，幥造物の応答低娍に更きを おくFB ケ゚インと, AMD のストロークの低減に面きをおくFB ゲインを裸数設定する。より具体的な設定については, 3.2 節で述 ベる。

\section{2 最大許容初期状態焦合}

外乱 $f=0$ を前提とすれば, ある特定の FB ゲイン $G_{m}$ を常に 用いるときの離散時間システム方程式は，

$$
X(k+1)=\left(A+B G_{m}\right) X(k)
$$

となる。このとき離散時間システム方程式 $(8)$ は, 初期值 $X(0)$ を 用いて,

$$
\begin{aligned}
X(k+1)= & \left(A+B G_{m}\right) X(k) \\
= & \left(A+B G_{m}\right)^{2} X(k-1) \\
& \vdots \\
= & \left(A+B G_{m}\right)^{k} X(1) \\
= & \left(A+B G_{m}\right)^{k+1} X(0)
\end{aligned}
$$


のように書き换えることができる。つまり，外乱入力のない構造物 であれば, 初期値 $X(0)$ からその後の応答を予測できる。

$$
\begin{aligned}
& \mathrm{AMD} \text { のストローク } x_{a} \text { を, } \\
& \qquad C=\left[\begin{array}{lllll}
0 & 0 & \cdots & 0 & 1
\end{array}\right]
\end{aligned}
$$

として,

$$
x_{a}(k)=C X(k)
$$

のように表せば, AMD のストローク $x_{a}$ は，

$$
x_{a}(k)=C\left(A+B G_{m}\right)^{k} X(0)
$$

AMD のストロークには限界があるので，ここで次のような肳 束条件を課す：

$$
\left|x_{a}(k)\right| \leq \rho
$$

この拘束条件は, 式 $(11)$ により $X(0)$ に関する以下の拘束条件に 置き換えることができる。

$$
\left|\frac{1}{\rho} x_{a}(k)\right|=\left|\frac{1}{\rho} C\left(A+B G_{m}\right)^{k} X(0)\right| \leq 1
$$

ここで,

$$
z(k)^{T}=\frac{1}{\rho} C\left(A+B G_{m}\right)^{k}
$$

と表すことにすれば, 拘束条件は

$$
\left|z(k)^{T} X(0)\right| \leq 1
$$

となる。

時刻 $N$ の時点まで拘束条件 $(15)$ を満たす $X(0)$ の集合 を $S(N)$ と表し, 許容初期状態集合 (Admissible set of initial state) と呼ぶ。 $S(N)$ は以下のように定義される :

$$
S(N)=\bigcap_{k=0}^{N}\left\{X(0) \| z(k)^{T} X(0) \mid \leq 1\right\}
$$

式 (16) を模式的に示せば, Fig.2 のようになる。

式 (8) の離散時間システム方程式が安定であれは，許容初期状態 集合 $S(N)$ は単調非增加で, 原点対象な凸多面体となることが知ら れている ${ }^{11}$ 。 $N \rightarrow \infty$ とすると, 吘容初期状態集合 $S(N)$ は, 下 限 $S$ に収束する。この下限 $S$ が最大許容初期状態集合と呼ばれ る11)。最大許容初期状態集合 $S$ は, 外乱のない場合の, FB ゲイ ン制御にかかわる拘束条件を满たす初期値の最大集合を意味する。 ここで, 許容初期状態集合 $S(N)$ と次のような関係にある集合 $\tilde{S}(N)$ を $S(N)$ の双対集合として定義する。

$$
\tilde{S}(N)=\left\{z(k):\left|X(0)^{T} z(k)\right| \leq 1, X(0) \in S(N)\right\}
$$

この双対集合 $\tilde{S}(N)$ は, $\pm z(k)(k=0 \sim N)$ を用いて, 次のよ うに表すことができる ${ }^{11)}$ 。

$$
\begin{aligned}
& \tilde{S}(N)= \\
& \left\{z: z=\sum_{k=0}^{N}\left(\alpha_{k}-\beta_{k}\right) z(k), \alpha_{k}, \beta_{k} \geq 0, \sum_{k=0}^{N}\left(\alpha_{k}+\beta_{k}\right)=1\right\}
\end{aligned}
$$

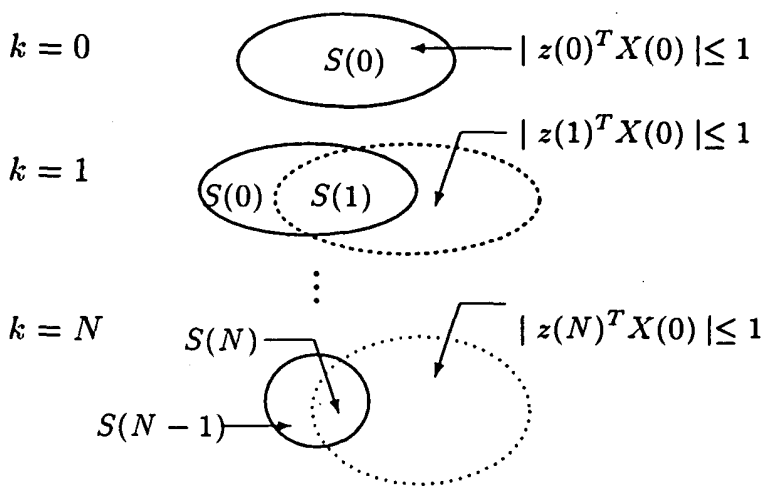

Figure 2 Admissible Set

式 (18) のように, 非負で総和が 1 となる係数をもつベクトルの 1 次結合を凸結合といい, 以下のように表す²)：

$\tilde{S}(N)=K\{z(0), \cdots, z(N),-z(0), \cdots,-z(N)\}$

ここで, $K\{\cdot\}$ はベクトル集合 $\{\cdot\}$ の凸結合を表す。

$S(N)$ と $\tilde{S}(N)$ は互いに双対集合の関係であるので, $S(N)$ が 単調非増加であれば, その双对集合 $\tilde{S}(N)$ は単調非減少となり，そ の上限 $\tilde{S}$ の双対集合が最大許容初期状態集合 $S$ となる。

$\mathrm{FB}$ ゲインの切り替えは, $S \in X(k)$ の判定を用いる。

$\tilde{S}$ の端点を $e_{1}, e_{2}, \cdots, e_{p}$ (すべて $2(n+1)$ 行のべクト ル) とすると,

$$
\tilde{S}=K\left\{e_{1}, e_{2}, \cdots, e_{p}\right\}
$$

および

$$
S=\left\{X(0):\left(e_{i}\right)^{T} X(0) \leq 1, i=1 \sim p\right\}
$$

が成り立つことが知られている ${ }^{11) 。 こ の よ う に, ~} \tilde{S}$ の端点により 最大許容初期状態集合 $S$ を表すことができるので, $S \in X(k)$ の 判定を, $\tilde{S}$ の端点 $e_{i}$ を用いて, $\left(e_{i}\right)^{T} X(k) \leq 1$ によって行う。 本論文では, $\tilde{S}$ の端点は吉田らの提案する方法 ${ }^{11}$ により求める。

\section{3 制御アルゴリスム}

外乱入力のないシステムでは, 状態 $X$ が一度最大吘容初期状態 集合に含まれれば，その後の状態 $X$ は必ず最大許容初期状態集合 に含まれる。つまり，最大許容初期状態集合内に初期值が含まれる ような FB ゲインを用いれば, 必ず拘束条件をみたす制御となる。 しかし，建榮·土木分野の制震では，地震，風などによる外乱入力が 存在するため, ある時刻で状態 Xが最大許容初期状態集合に含ま れていたとしても, その後の保証とはならない。しかも，地震や風 などの外乱は, 時刻歴及び継続時間をあらかじめ予测することはで きない。

そこで，毎時刻の状態を初期值とみなし，毎時刻ことに，状態を 最大許容初期状態集合に含む FB ゲインを全て選び出す。選び出さ れた複数の FB ゲインのうち, AMD のストロークに対する重み 


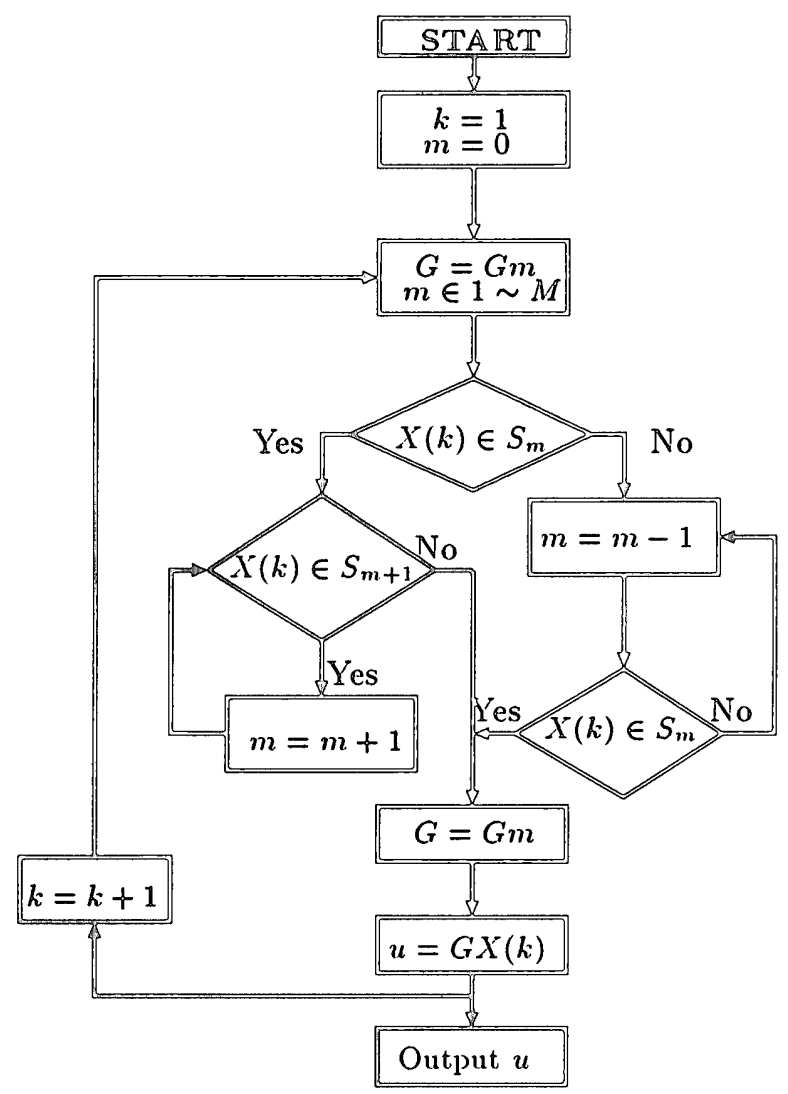

Figure 3 Control Algorithm

が小さいものほど, AMD のストロークを大きく饰うことにな り，高い制御勃界につながる。したがって，高い制御勃界を得る ために, AMD のストロークに对する雷みが最も小さい FB ゲイ ンを用いて，制御力 $u$ を決定すればよい。

上記の制御アルゴリズムのフローチャートを Fig.3に示す。た だし， $M$ 個のゲインのうち, AMD のストロークの雷みが最も大 きい(つまり最も制御勃果の低い) ゲインを $G_{1}$, 最も小さい(つま り最も制御动果の高い) ゲインを $G_{M}$ とし, 各ゲイン $G_{m}$ について の最大許容初期状態鼠合を $S_{m}$ とする。

3 制震效棵の確認シミュレーション

\section{1 制御詨象モデル}

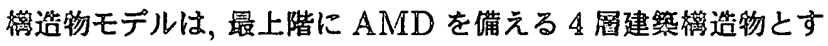

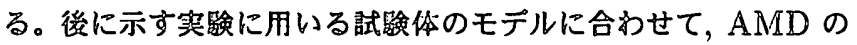

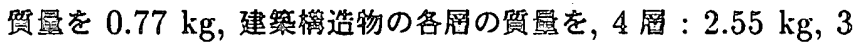
虽 : $1.62 \mathrm{~kg}, 2$ 層: $1.47 \mathrm{~kg}, 1$ 層: $1.47 \mathrm{~kg}$ とする。AMDの ストローク限界は $1.2 \mathrm{~cm}$ である。また, 各次の固有振陻数と減哀

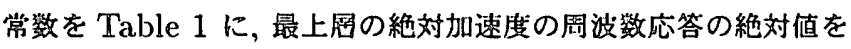
Fig.4にそれぞれ示す。

制震効果の碓認にあたっては，構造物モデルの 1 次固有振動数近 傍に卓越振县潄を持つTaft 1952 NS を地震波として用いた。

\section{2 シミュレーション結果}

$M=3$ として, LQG 理論にもとづいて, $G_{1}, G_{2}, G_{3}$ の 3 つのゲインを以下のように設定する。
Table I Narural Frequencies and Dampiong Rarios

\begin{tabular}{ccc}
\hline mode & natural frequency & damping ratio \\
\hline 1 & $2.8[\mathrm{~Hz}]$ & 0.019 \\
2 & $8.9[\mathrm{~Hz}]$ & 0.088 \\
3 & $14.8[\mathrm{~Hz}]$ & 0.0098 \\
4 & $19.6[\mathrm{~Hz}]$ & 0.0014 \\
\hline
\end{tabular}

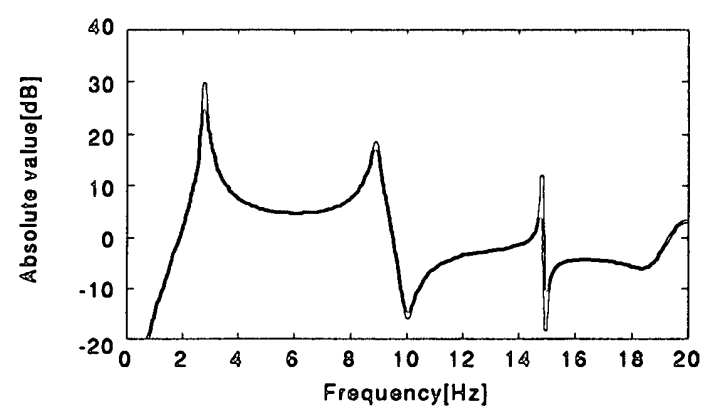

Figure Absolute Value of Frequency Response of Top-floor Absolute Acceleration

式 (4) の評価関数 $J$ は, 状態を評価する $X^{T} Q_{m} X$ と制御力 を評価する $r u^{2}$ の項から成っている。

まず, $X^{T} Q_{m} X$ の項に注目すると，

$$
\begin{aligned}
X^{T} Q_{m} X=\dot{x}_{1}^{2} q_{1}^{\prime} & +\cdots+\dot{x}_{4}^{2} q_{4}^{\prime}+\dot{x}_{a}^{2} q_{a}^{\prime} \\
& +x_{1}{ }^{2} q_{1}+\cdots+x_{4}{ }^{2} q_{4}+x_{a}{ }^{2} q_{a}
\end{aligned}
$$

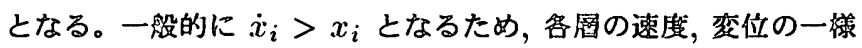
な低減を制御目橪とするのであれば, 謤価関效中において，各圆の 速度, 変位を同じレペルで考澏できるように $Q_{m}$ を設定する必要が ある13)。具体的には，非制御時において

$$
\dot{x}_{1}^{2} q_{1}^{\prime}=\cdots=\dot{x}_{4}^{2} q_{4}^{\prime}=x_{1}{ }^{2} q_{1}=\cdots=x_{4}{ }^{2} q_{4}
$$

が成り立つように, $q_{a}$ 以外の雷みの比を以下のように設定する。

$q_{1}^{\prime}: q_{2}^{\prime}: q_{3}^{\prime}: q_{4}: q_{a}^{\prime}: q_{1}: q_{2}: q_{3}: q_{4}$

$=7.17: 2.38: 1.40: 1: 0.001: 3000: 840: 440: 320$

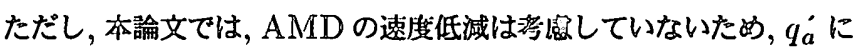
ついては極端に小さな敏値を設定している。

つぎに, $X^{T} Q_{m} X$ と $r u^{2}$ の項の関係に注目する。LQG 理論 では，評価関效を最小にするようにFB ゲインを決定するため, FB ゲインの大きさは $Q_{m}$ の各要素之 $r$ の相対的な大きさの閣係に依 存する。 $Q_{m}$ の各要素が相対的に小さいと, 制御勃果よりも制御力 の節約に重きをおくFB ケ゚インとなり, $Q_{m}$ の各要菜が相対的に大 きいと制御勃果に重きをおくFB ゲインとなる。

そこで, FB ゲインの主目的が制御力の節約から制御勃果人と㚆化

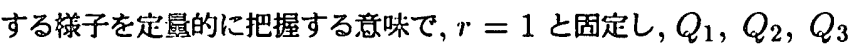
の各要素の比は一定としたまま, 各要素の值を連続的にスカラー倍 して変化させ, 制御力 $u$ の RMS 值に対する最上階の応答変位お よび AMD のストロークの RMS 値の関係を調べる。 


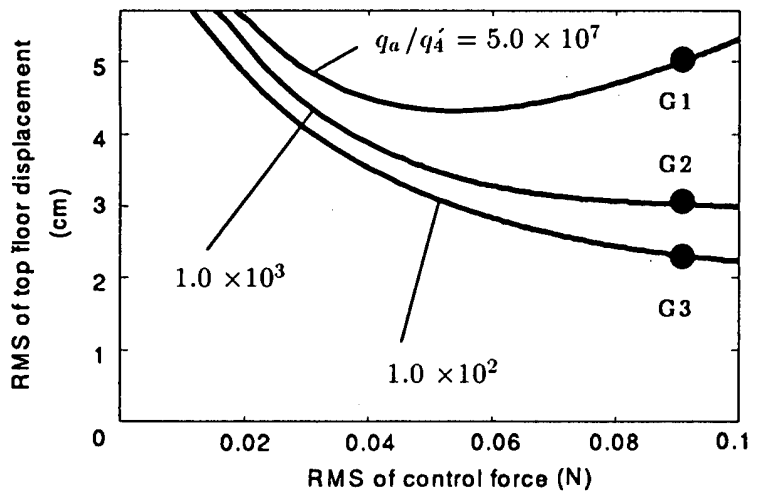

Figure 5 Relationship between Control Force and Top-floor Displacement

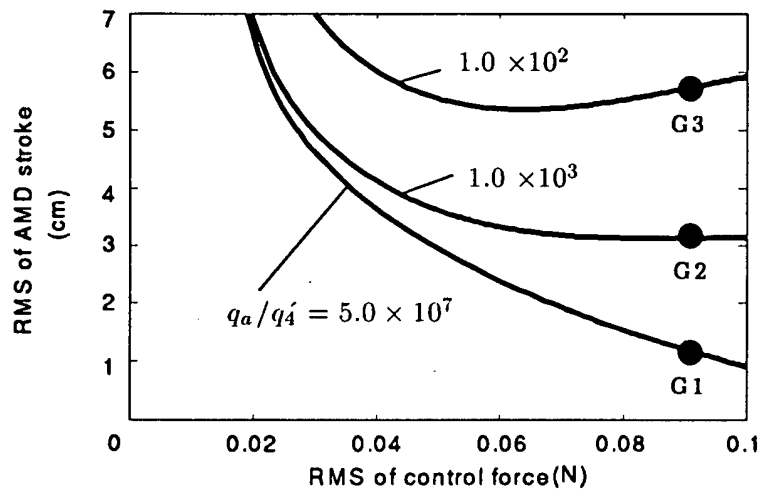

Figure 6 Relationship between Control Force and AMD Storke

$$
\begin{gathered}
\text { ここで } q_{a} / q_{\dot{4}} \text { の比として } \\
Q_{1}: 5.0 \times 10^{7} \\
Q_{2}: 1.0 \times 10^{3} \\
Q_{3}: 1.0 \times 10^{2}
\end{gathered}
$$

の 3 つのケースを想定している。

制御力 $u$ の RMS 值を横軸にとり, Fig.5 の維軸に最上首の 変位 $x_{4}$ の RMS 值を, Fig.6 の縦軸に AMD のストローク $x_{a}$ の RMS 值を示す。Figs.5, 6 からも， $Q_{1}$ は $Q_{2}$ に比べて制御効 果よりも AMD のストロークの低隇に重きを置いた重み行列であ り, $Q_{3}$ は $Q_{2}$ に比べて $\mathrm{AMD}$ のストロークの低減よりも制御効果 に重きを置いた重み行列であることが確認できる。

本論文では，必要となる制御力 $u$ が，FB ゲインによらず一定 となるように，また AMD ストロークの RMS 值については $G_{1}$ が $G_{2}$ の約半分となるなるように, FB ゲインを選んだ。各 $G_{m}$ に ついて, Figs.5, 6 に $G_{1}, G_{2}, G_{3}$ の 3 つのゲインを決定した点 を・で表している。 $G_{1}, G_{2}, G_{3}$ それぞれに対しての q4の值は

$$
\begin{aligned}
& G_{1}: q_{4}^{\dot{\prime}}=4.6 \times 10^{-3} \\
& G_{2}: q_{4}^{\prime}=2.1 \times 10^{2} \\
& G_{3}: q_{\dot{4}}^{\prime}=1.4 \times 10^{2}
\end{aligned}
$$

である。

以上のようにして $, G_{1}, G_{2}, G_{3}$ が決定されたので, 最大加速度 の変化に対する可変 FB ゲイン制御の効果を考察する目的で，最 上層の変位の $\mathrm{RMS}$ 值と最大值, AMD のストロークの最大值を それぞれ Figs.7 〜 9 に示す。

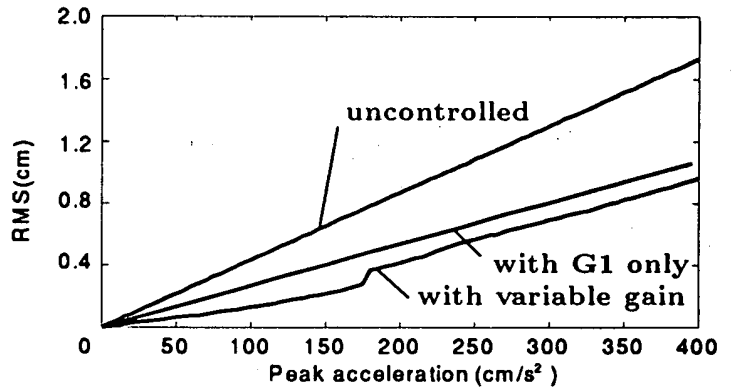

Figure 7 RMS of Top-floor Displacement

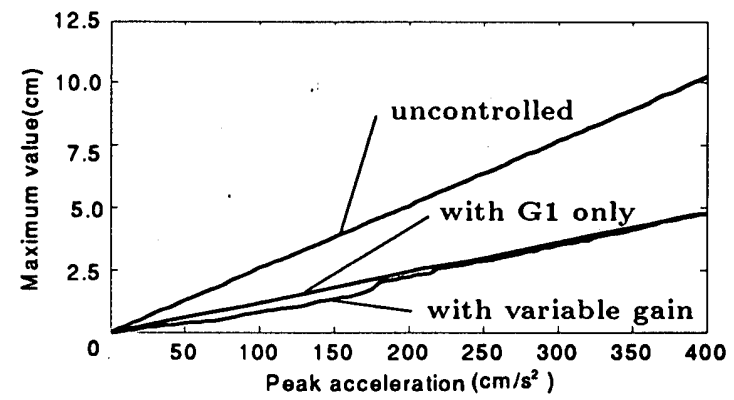

Figure 8 Maximum Value of Top-floor Displacement

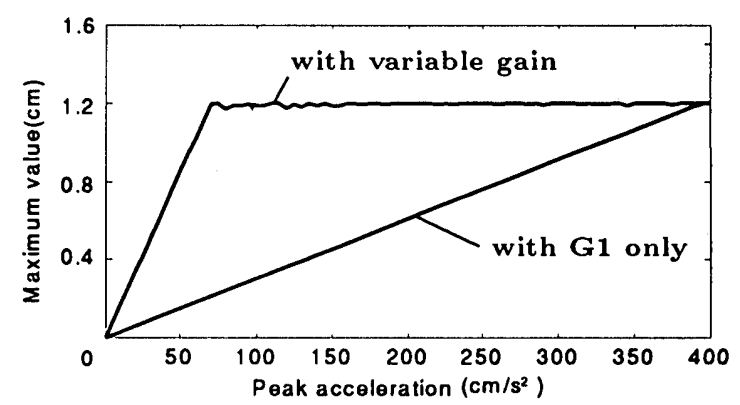

Figure 9 Maximum Value of AMD Stroke

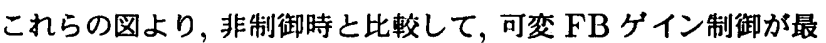
大加速度の大きさによらず, AMD のストロークの限界内で, 最上 層の変位の RMS 值, 最大值をともに低滅させていることが確認 できる。

$G_{1}$ のみの制御と比較すると, 次のことがわかる：i) 最大加速度 の大きさによらず最上首変位の RMS 值が小さな值となり，特に 最大加速度が小さい間は， $G_{1}$ のみの制御の半分ほどに低減される; ii) 最上首変位の最大值は, RMS 值之同様小さい値を示すが, 最 大加速度が大きくなるとほぼ同じ值となる；iii）小地震のうちか ら AMD のストロークを限界まで使用し，AMD の性能を活用し た効果的な振動制御が行える；iv) 制御が適用できる地震の範囲 がわずかではあるが広がる。

最大加速度を $300 \mathrm{~cm} / \mathrm{s}^{2}$ とした場合の最上首の変位, AMD の ストロークの時刻歴応答とゲイン切り替えの様子を Fig.10 (a) (c)に示す。ただし, Fig.10 (b) 中の点線は AMD ストロークの 限界値を表す。これらの図からも，AMD のストロークの限界内で $\mathrm{FB}$ ゲインを効率良く切り替えて, 効果的な制御を行っていること が確認できる。 


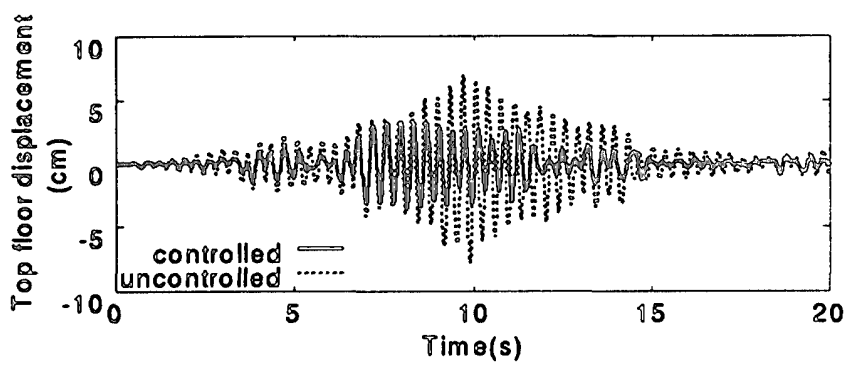

(a) Top floor displacement

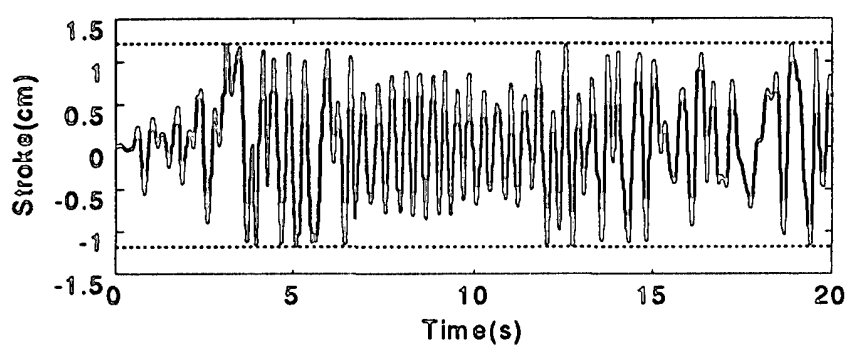

(b) AMD stroke

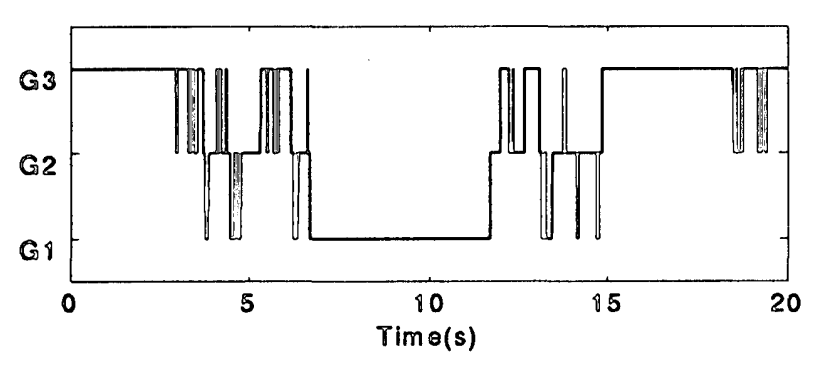

(c) Feedback gain

Foigure 10 Responses for Taft $1952 \mathrm{NS}$ with Peak Acceleration $=300 \mathrm{~cm} / \mathrm{s}^{2}$

以上により, 杂諭文の可㚆フィードバックケ゚イン制御の有勃珄を シミュレーションにより示した。

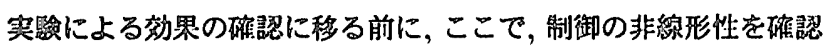
する意味で, 制御対泥モデルの 1 次固有振動败 $2.8 \mathrm{~Hz}$ の $\sin$ 波を入

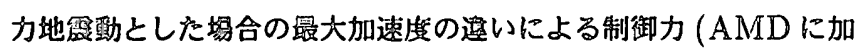

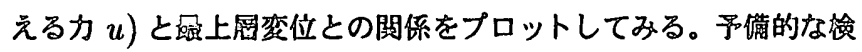
佮を通して，この $\sin$ 波に対しては最大加速店がほぼ $70 \mathrm{~cm} / \mathrm{s}^{2}$ を 解えるとゲイン $G_{1}$ のみが適用され，ほぼ $45 \mathrm{~cm} / \mathrm{s}^{2}$ 以下となる と常時ゲイン $G_{3}$ か゚適用可能となることから，最大加恶度として $45,55,70 \mathrm{~cm} / \mathrm{s}^{2}$ を設定している。Fig.11 (a) は, ゲイン $G_{1}$ を

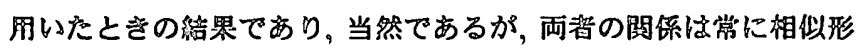

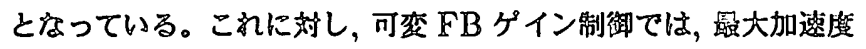
に㤁し゚て, AMD のストロークに余签のあるうちは大をな制御力を 做って応答低減を行っている。つまり, 可変 $F B$ ゲイン制御は, 裋 数のFB ゲインを用いるため，外乱の大きさに合わせて最道な制御 を行っている。

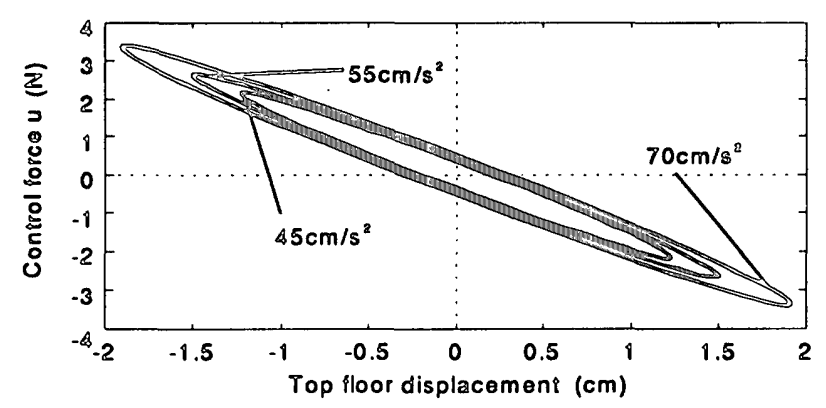

(a) $G_{1}$ only

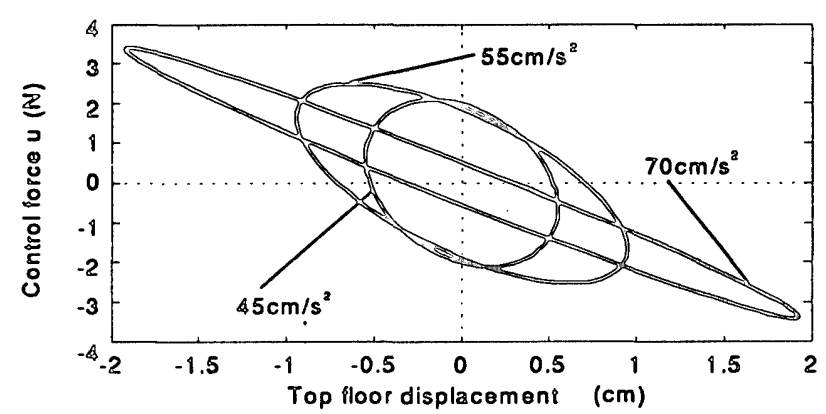

(b) Variable feedback gain

Figure 1 I Relationshoip between Control Force and Top-floor Displacement

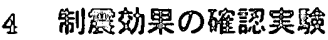

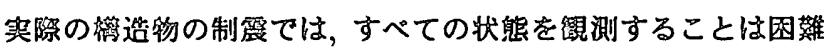
である。そこで, 覞测できる状熊のみで制震を行うた的に，一般化 交位と一船化速度からなる状態により表される低次元化システム を用いる。実験においては，AMD の速崔，ストロークと㩐造物 の最上首の地面との相対速度，相対変位により，モート゚変換を用い て，AMD と 1 次モードの一般化座祭からなるシステムに低次元 化する14)。

FB ケ゚インは, シミュレーション同様, $\mathbb{L Q G}$ 理論から书めた $G_{1}, G_{2}, G_{3}$ の 3 個のゲインを用いる。 $G_{3}, G_{2}, G_{1}$ の順に, ス トロークを大をく㑑い制御勃果をあけ゚るゲインとなっている。实 駼で注，1 次モードに詨する一般化座㯲および AMD の钦きによ り，低次元化モテルをを楬成する。1 次モ一ト゚の一船化交位を $\eta_{1}$ と すると，この場合の状態 Xは

$$
X=\left[\begin{array}{llll}
\dot{\eta}_{1} & \dot{x}_{a} & \eta_{1} & x_{a}
\end{array}\right]^{T}
$$

であり，Xに相当する重み行列は，

$$
Q_{m}=\operatorname{diag}\left[q_{1}, q_{a}, q_{1}, q_{a}\right]
$$

となる。AMD のストロークに封する重み $q_{a}$ と 1 次モードの一

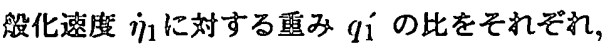

$$
q_{a} / q_{\mathrm{i}}=2.5 \times 10^{3}, 5.0 \times 10^{2}, 1.0 \times 10^{2}
$$

として求めた $F B$ ゲインを $G_{1}, G_{2}, G_{3}$ とする。白色雑音入力 時の $\eta_{1}$ の RMS 值により $G_{1}, G_{2}, G_{3}$ による制御勃果を比乹す れば, 


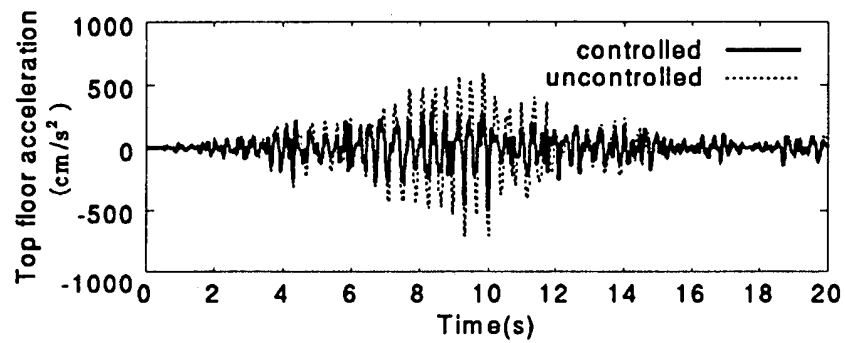

(a)Top floor acceleration

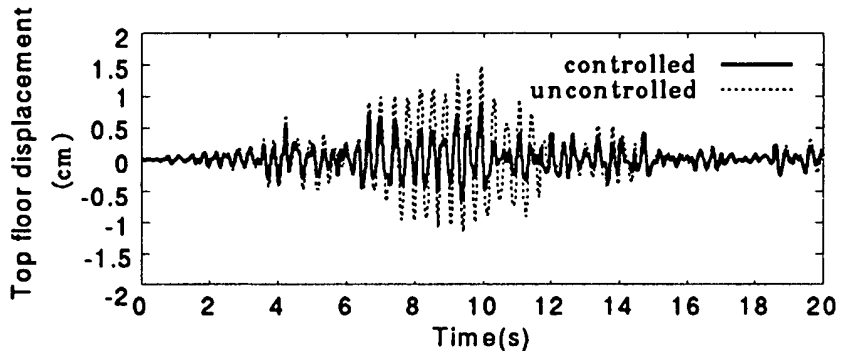

(b)Top floor displacement

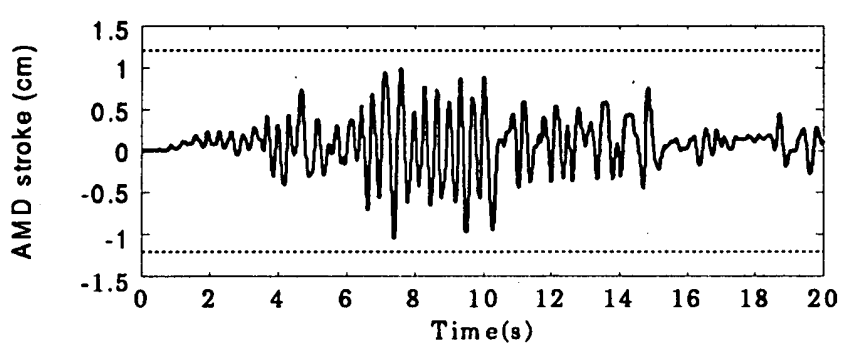

(c)AMD stroke

Figure 12 Responses for Taft 1952 NS with Peak Acceleration $=260 \mathrm{~cm} / \mathrm{s}^{2}$

$\left[G_{2}\right.$ による制御 $] /\left[G_{1}\right.$ による制御 $]=0.79$

$\left[G_{3}\right.$ による制御 $] /\left[G_{1}\right.$ による制御 $]=0.70$

AMD ストロークの RMS 值により，同㥞の比較を行えば，

$\left[G_{2}\right.$ による制御 $] /\left[G_{1}\right.$ による制御 $]=1.6$

$\left[G_{3}\right.$ による制御 $] /\left[G_{1}\right.$ による制御 $]=2.3$

次に, 最大加速度 $260 \mathrm{~cm} / \mathrm{s}^{2}$ と $380 \mathrm{~cm} / \mathrm{s}^{2}$ の Taft $1952 \mathrm{NS}$ に より実験体を加振する。サンプリング時間 $\Delta t$ は 0.005 秒とする。

それぞれの場合の最上莌の絶対加速度, 相対变位, AMD のスト ロークを Figs.12，13 に示す。これらの結果より，可変 FB ゲイ ン制御による実験モテルの絶対加速度および相対変位の低減が入力 地震動の大きさによらず破認でき, AMD のストロークを有効に活 用していることがわかる。

Figs.14, 15 に, $260 \mathrm{~cm} / \mathrm{s}^{2}$ と $380 \mathrm{~cm} / \mathrm{s}^{2}$ それぞれ場合のゲ インの切り替えの様子を示す。両図より, 入力地震波の大きさに合 わせてゲインを変化させた効率の良い制御を行っており, 可変 FB ゲイン制御の有効性が確認できる。

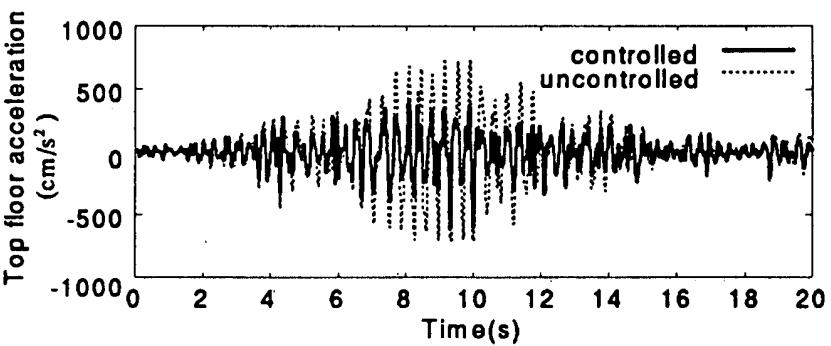

(a)Top floor acceleration

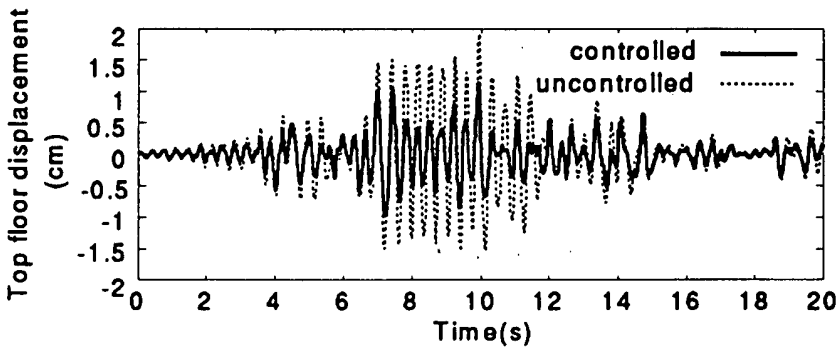

(b)Top floor displacement

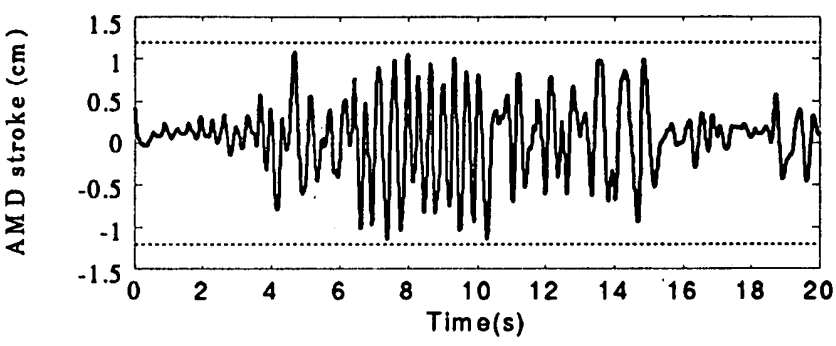

(c)AMD stroke

Figure 13 Responses for Taft 1952 NS with Peak Acceleration $=380 \mathrm{~cm} / \mathrm{s}^{2}$

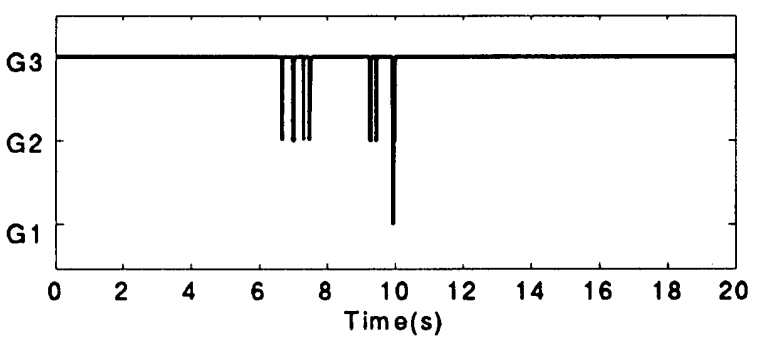

Figure 14 Feedback Gain Selection (Peak Acceleration $=260 \mathrm{~cm} / \mathrm{s}^{2}$ )

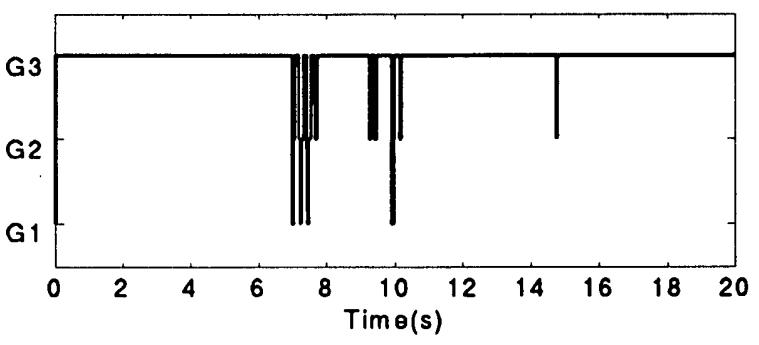

Figure 15 Feedback Gain Selection

$\left(\right.$ Peak Acceleration $\left.=380 \mathrm{~cm} / \mathrm{s}^{2}\right)$ 


\section{马 まと的}

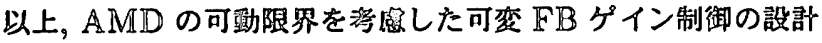

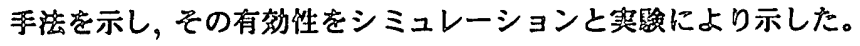
結諭をまと的ると，

1. 外乱のあるアクティプ制虔においても，昆大許容初期状態焦

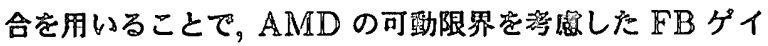
ンの切り箬えが可能となる。

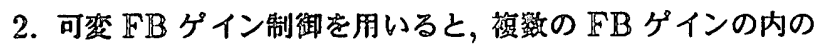
1 つのみを便う制御よりも適用でさる地震の簛囲が搪がる。

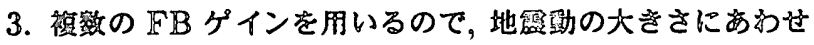
て，制御装置の可動限界の中で勃率の良い制震が可能とな り, AMD のストロークを有勃に使い，大地震への対応も可 能となる。

今後は, AMD への制御カとストローク両方の性能限界を海惊 する可㕠 $\mathrm{FB}$ ケ゚イン制御への昿張を行う予定である。

本研究は，日本学術振興会 未采開拓学術研究推進赇對研究プロ

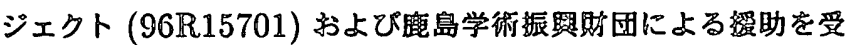
けた。

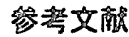

1) A.Nishitani,Y.Nitta,N.Yamada : Variable Gain-Based Structural Control Considering the Limit of AMD Movement,Proceedings of the 35th IEEE Conference on Decision and Control,1996.12

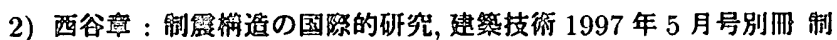

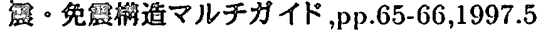

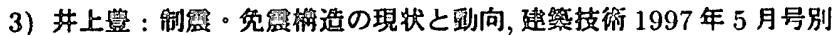

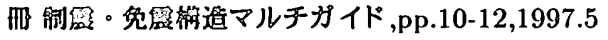

4) B.Indrawan,T.Kobori,M,Sakamoto,N.Koshika : Analytical Study on a New Power-Efficient Active Control Method, Second.Int.Conf.MOVIC,pp.687-692,1994.8

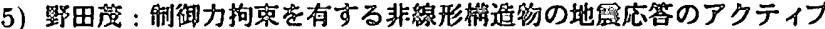
コントロール,アクティプ制振シンポジウム諭文焋,pp.65-70,1992.3

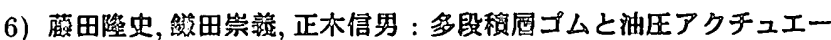
夕を用いた高屏趣物制振用アクティプ・マスダンパの基磁的研究

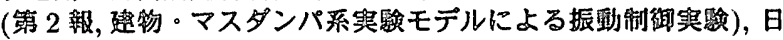

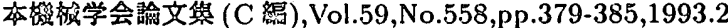

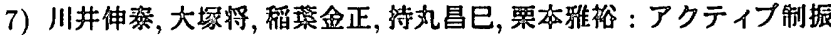

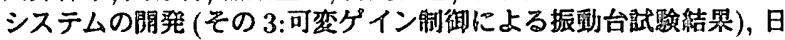

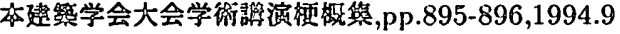

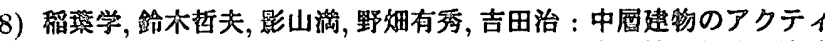

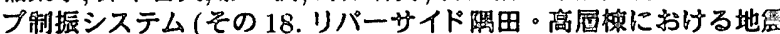

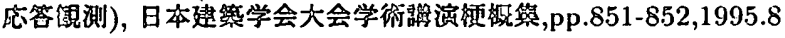

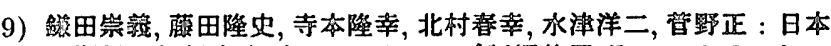

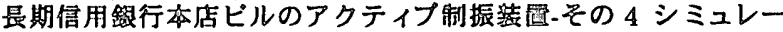

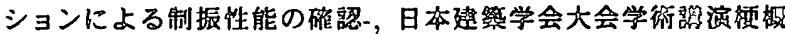
舞,pp.981-982,1994.9

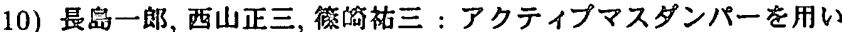

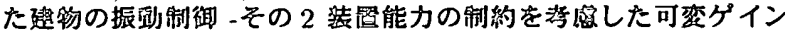

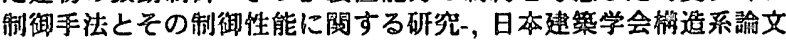
䇣,No.483,pp.39-49,1996.5

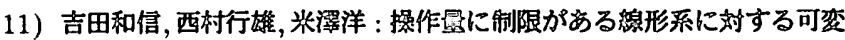

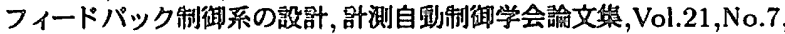
pp.677-683,1985.7

12) 坊川是, 中山弘隆, 谷野哲三: 線形代数と凸解析, コロナ社,1991

13) T.Kobori,N.Koshika,K.Yamada,Y.Ikeda : Seismic-Response -Controlled Structure with Active Mass Driver System(Part1)Design,Earthquake Engineering and Sturctural Dynamics,Vol.20,No.2,pp133-149,1991.2

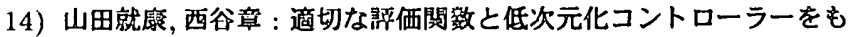

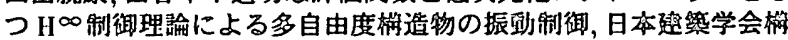

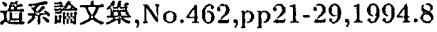

(1997年 7 月 10 日原稿受理， 1997 年 9 月 5 日採用決定） 